\title{
Influence of Weather Conditions on Infection of Peach Fruit by Taphrina deformans
}

\author{
V. Rossi, M. Bolognesi, and S. Giosuè
}

Institute of Entomology and Plant Pathology, "S. Cuore" Catholic University, Via E. Parmense 8429100 Piacenza, Italy. Accepted for publication 4 August 2007.

\begin{abstract}
Rossi, V., Bolognesi, M., and Giosuè, S. 2007. Influence of weather conditions on infection of peach fruit by Taphrina deformans. Phytopathology 97:1625-1633.

The effect of environment on the infection of peach fruit by Taphrina deformans was investigated using orchard observations under natural conditions (in 2001 to 2004) or in trees managed in such a way to exclude rainfall. These conditions were then validated using pot-grown peach plants exposed to single infection events and independent orchard observations. Leaf curl incidence was related to rainfall, length of wet periods, and the temperature during wetness and during the incubation period, as well as to the developmental stage of flowers and fruit. Weather condi-

rainfall and the duration of the wet period triggered by rainfall played a key role in infection occurrence. The minimum rainfall required for infection was $12 \mathrm{~mm}$, with at least $24 \mathrm{~h}$ of wetness interrupted by no more than $4 \mathrm{~h}$. No infection occurred when temperature was $\geq 17^{\circ} \mathrm{C}$ during the wet period or $>19^{\circ} \mathrm{C}$ during incubation. Disease symptoms appeared on fruit after approximately 3 weeks of incubation, which is equivalent to 240 - to 290 -degree-days (base $0^{\circ} \mathrm{C}$ ). The period for fruit infection was relatively short being from petal fall until air temperature remained greater than $16^{\circ} \mathrm{C}$. During this period, the incidence of fruit that developed symptoms was closely related to the number of favorable events and the total wetness duration during such events.
\end{abstract} tions before petal fall did not influence fruit infection. After petal fall,
Additional keywords: peach leaf curl, Prunus persica.
Leaf curl, caused by Taphrina deformans (Berk.) Tul., is a common disease of peach and nectarine trees (Prunus persica L.) wherever susceptible hosts are grown (9). Leaf curl first appears in spring as reddish areas on developing leaves; these areas become thickened and puckered, causing leaves to curl and severely distort. Affected leaves later turn yellow or brown and usually abscise (24). Under the right conditions, the disease causes severe early defoliation and crop loss (23). Extensive defoliation can lead to a reduced fruit crop the following year, and if leaf curl infection builds up and is not adequately controlled for several years, the tree may decline and need to be removed (11).

The leaf curl pathogen also infects flowers and fruit (2). Blossoms are distorted, shrivel and usually fail to set fruit. Raised, warty, discolored areas develop on young fruit surfaces which become corky and tend to crack (34); infected fruit can also fall early in the season. Disease symptoms are more evident on nectarine than on peach fruit.

It is generally believed that fruit become infected only rarely $(2,14,24)$. Fruit infection is more common in northern Italy where fruit have become infected in 10 out of the last 15 years, with incidences ranging from 1 to $60 \%$ and in 5 years, more than $20 \%$ of fruit displayed symptoms (25). This infection probably remains unnoticed by inattentive observers, because infected fruit are difficult to detect within the plant canopy and many of them drop prematurely.

Infections on shoots and fruit seem not to be closely related (5). Shoots are most susceptible to leaf curl between bud break and petal fall (27), while the first symptoms on fruit usually appear later, during fruit development. In 1993 and 1998, for example, more than $80 \%$ of shoots were infected, while fruit were disease

Corresponding author: V. Rossi; E-mail address: vittorio.rossi@ unicatt.it

doi:10.1094/PHYTO-97-12-1625

(c) 2007 The American Phytopathological Society free; in 2001, about $40 \%$ of fruit were infected, with $80 \%$ of shoots being severely curled (25).

Weather conditions favoring shoot infection have been defined in relation to (i) rainfall, with a minimum of $3 \mathrm{~mm}$, (ii) wet periods of at least $12.5 \mathrm{~h}$, (iii) air temperature during wetness $<16^{\circ} \mathrm{C}$, and (iv) temperature during the incubation period $<19^{\circ} \mathrm{C}$ (27). On the contrary, no information is available on conditions leading to infection of fruit.

The objectives of this study were (i) to determine the period of fruit infection by $T$. deformans in relation to the developmental stage of flowers and fruit, (ii) to investigate the relationships between weather conditions and infection and determine minimum conditions for infection to occur, and (iii) to verify these minimum conditions using independent data. Observations were made for a 4-year period (2001 to 2004) in a peach orchard severely affected by leaf curl and complemented with experiments managed in such a way to exclude rainfall. Pot-grown peach plants exposed to individual rainfall events and observations made in peach orchards between 1996 and 2005 were used to verify the previous observations.

\section{MATERIALS AND METHODS}

Disease observations in orchards. Between 2001 and 2004, observations were made in peach orchards located in Zattaglia (Ravenna), a peach-growing area in the hills of the southern Po Valley (about $300 \mathrm{~m}$ above sea-level). Three cultivars were studied, all highly susceptible to leaf curl (32): 'Venus' in 2001 and 2002; 'Silver Star' in 2003, and 'Star Bright' in 2004. Trees were 14 to 16 years old in 2000 . They were palmate-trained, spaced $4.6 \mathrm{~m}$ between rows and $3 \mathrm{~m}$ between plants, and cropped following the usual practice, but were not sprayed with fungicides. Hourly meteorological data of temperature, relative humidity, rainfall, and leaf wetness duration were recorded by a thermo-wetness-hygrograph and a rainfall recorder (SIAP, Bologna, Italy) placed between rows at $1.8 \mathrm{~m}$ above-ground. The leaf wetness 
sensor measures the conductivity value (in Mohm) of a stratified fiberglass surface to which two electrodes have been applied. This produces an on/off output, wet $<1$ Mohm, dry $>1$ Mohm. Significant meteorological events, like the presence of snow, dew, or fog, were recorded by visual observations.

Ten trees were inspected twice weekly. At each inspection, data were recorded for host growth stage using the $\mathrm{BBCH}$ phenological scale (3) and for disease incidence on shoots and fruit. Three hundred shoots were randomly chosen, tagged, and classified as symptomless or having leaf curl symptoms; fruit also were observed for the disease symptoms. At the end of May, 100 random fruits per plant were picked and classified as healthy or affected.

Using meteorological data collected in the orchard, all periods with at least $12 \mathrm{~h}$ of wetness triggered by rainfall, dew, or fog were identified (27). Interruptions in wetness of less than $4 \mathrm{~h}$ were assumed not to be influential (27). The total wetness duration (WD, h), total rainfall $(\mathrm{R}, \mathrm{mm})$, and average temperature (Tw, ${ }^{\circ} \mathrm{C}$ ) were calculated for each wet period. Based on the results obtained from the experiment with pot-grown plants, it was hypothesized that disease symptoms caused by any wet period should appear on fruit after an incubation of 240- to 290-degreedays $\left(\mathrm{DD}\right.$, base $0^{\circ} \mathrm{C}$ ), and that symptoms from one infection should continue to appear over 3 to 4 days. When this estimated period coincided with the period when disease symptoms actually appeared on fruit, the corresponding wet period was considered as a true infection period. All the wet periods were classified into two groups by using the above mentioned method, (i) periods with infection, and (ii) periods without infection. The distribution of data within each group was then analyzed by calculating summary statistics and by drawing box and whisker plots. Statistical differences between the two groups were tested by the $t$ test for means and by the Kolmogorov-Smirnov test for distributions under the null hypothesis of equality of the two data sets.

The probability of fruit infection to occur was calculated using the logistic regression procedure of SPSS version 11.5 (SPSS Inc., Chicago, IL). Cases for calculating regression were the wet periods, the dependent variable was the dichotomic response "with" (value 1) or "without" (value 0) infection, and the independent variables were WD, R, Tw, and all their interactions (WD by $\mathrm{R}$, WD by Tw, etc.). The best regression model was obtained using a conditional upward stepwise selection of the independent variables, with $P \leq 0.05$ for including variables and $P \geq 0.1$ for their exclusion. Model accuracy was evaluated based on the standard error of parameters. Significance level was calculated by the Wald's statistic, the dimension of deviance, the number of iterations (1), and the coefficient of determination, adjusted following Nagelkerke (22).

Experiments with covered plants. In 2003, three branches of 10 trees of a 'Star Bright' orchard in Zattaglia, which had been severely affected by leaf curl in the previous season, were covered by plastic bags to exclude rainfall from petal fall ( 8 April) to the end of May, while three branches were not covered. Bags were applied before all rainfall events and removed at the end of rainfall to reduce influences on air temperature. At mid-June, all the fruit on these branches were picked and classified as healthy or affected.

In 2004, 16 contiguous peach trees in the same orchard at Zattaglia were protected from rainfall by a permanent cover of polycarbonate (4 $\mathrm{mm}$ of thickness) placed over the plants (about $1 \mathrm{~m}$ over the top) before bud break and maintained there until the end of May. Mobile covers were also prepared with polyethylene sheets and installed to laterally close the plants only on the following occasions, (i) during rainfall to prevent natural wetting, and (ii) during periods of artificial wetting to maintain humidity. Wet periods were obtained using overhead sprinklers operated at low water pressure in such a way as to maintain wet plant sur- faces by a fine misting of water for $48 \mathrm{~h}$, with minimum dripping of water within plant canopies. One group of two contiguous plants was wetted once during the season for $48 \mathrm{~h}$ between 24 and 26 March (full flowering). A second group was wetted once at weekly intervals until mid-May. At the beginning of June, all fruit were picked and classified as symptomless or having leaf curl symptoms (about 300 fruits per plant on average).

Hourly data of temperature and wetness duration were recorded by a thermo-wetness-hygrograph (SIAP, Bologna, Italy) placed within the canopies under the cover.

Experiments with potted plants. Three-year-old pot-grown 'Silver Star' plants were maintained in a refrigerated chamber at about $4^{\circ} \mathrm{C}$ to prevent bud break. Groups of three potted trees were placed in a greenhouse at weekly intervals and maintained $8 \mathrm{~h}$ in darkness at about $8^{\circ} \mathrm{C}$ and $16 \mathrm{~h}$ in daylight at $15^{\circ} \mathrm{C}$. At blooming, these plants were pollinated manually. Plants from each group were exposed under the canopy of field-grown peach trees showing severe leaf curl symptoms when young fruit of the potted plants was about $2 \mathrm{~cm}$ in diameter. The potted plants were maintained under the trees until the first rainfall. Plants were removed after the wet period, triggered by rainfall, ended, and incubated in a growth chamber at 10 to $14^{\circ} \mathrm{C}$. Twelve groups of plants were exposed between mid-March and mid-May of 2004 and 2005. Plants were inspected daily to determine the time of disease appearance; the incidence of infected fruit was calculated as a percentage of the total number of fruit (16 to 31 fruits per group of plants). Time elapsed between exposure to rainfall and symptom onset was expressed as both number of days and DD. To calculate $\mathrm{DD}$, the daily average temperature was accumulated, with a base of $0^{\circ} \mathrm{C}$. The average temperature during incubation (Tinc) was calculated for plants where there was infection. When the disease did not appear, average temperature was calculated over the 21 days following the beginning of rainfall. Hourly meteorological data were recorded by an automatic station (Davis Instruments, San Francisco, CA) located $5 \mathrm{~m}$ from the potted plants. The leaf wetness sensor measures the conductivity across a grid with a bi-polar excitation circuit and displays it on a scale from 0 (dry) to 15 (values $>0$ were considered wet).

Comparisons with historical data. The minimum conditions for infection to occur were defined based on the results from the previously described experiments. These conditions were validated using independent data collected between 1996 and 1999, and in 2005. Details on these data have been published (33). Percent disease incidence was assessed in untreated plots of experimental orchards managed to compare fungicides against leaf curl. Assessments were made at the end of May on a sample of 400 fruits collected randomly, and percent incidence of symptomatic fruit was calculated. Eleven orchards (year $\times$ location) were considered in total, all located in the eastern Po Valley (Italy).

Periods with favorable conditions of rainfall, wetness duration, and temperature occurring between petal fall and the end of May were determined for each experiment. The number of favorable periods and the total wetness (as a summation of the wet hours found in each favorable period) were compared with the incidence of fruit infected by drawing a three-dimensional scatter plot and by calculating the Pearson's coefficients of correlation.

\section{RESULTS}

Fruit infection in the orchard. Fruit infection was observed in 3 of the 4 years. In a few cases severely deformed fruit appeared at the time of shuck split; in most cases the first visible symptoms of infection on fruit consisted of small groups of hyaline cells which proliferated in a callus-like formation on the fruit skin, scattered or grouped in large areas that covered 70 to $80 \%$ of the fruit surface. These proliferations were usually more abundant on the calyx tip where the film of water remained longer after a rain- 
fall than on lateral surfaces. These proliferations became reddish in color with time and assumed the typical aspect of raised and wrinkled areas. The severely deformed fruit fell before maturity, while the majority of fruit showing typical symptoms remained in the tree.
In 2001 (Fig. 1A), fruit showed disease symptoms in late April to early May, with a final incidence of $39 \%$. Disease incidence on shoots was $86 \%$. Based on the estimated length of incubation, the infections that caused these symptoms likely occurred between the end of March and the first half of April. During this period,
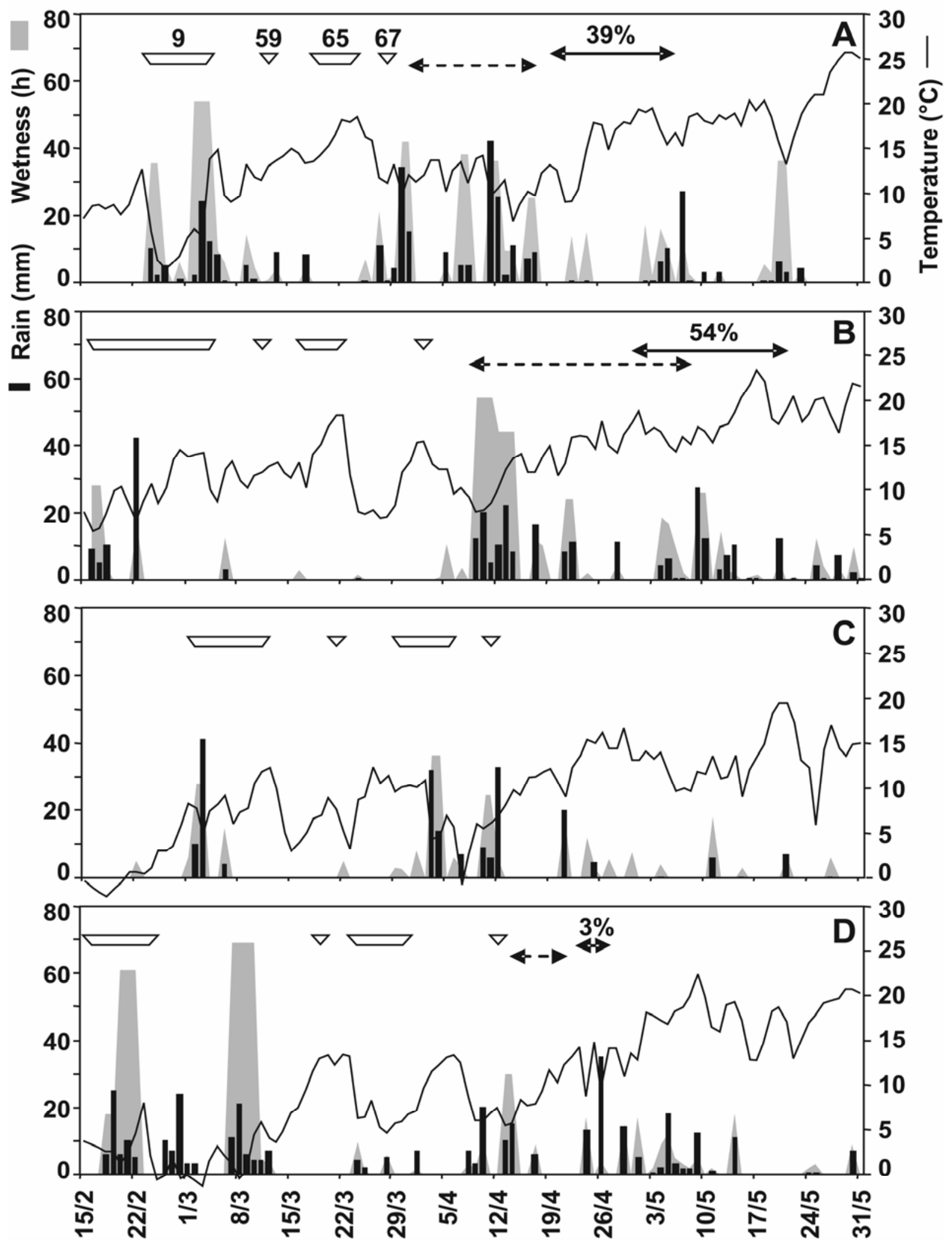

Fig. 1. Daily air temperature, rainfall, and wetness duration (as hours of continuous wetness, interrupted for a maximum of $4 \mathrm{~h}$ ) in the peach orchards located at Zattaglia (northern Italy) in A, 2001, B, 2002, C, 2003, and D, 2004. Arrows ( $\nabla$ ) identify the growth stages according to the BBCH scale (3) (9, green tip; 59, most flowers forming a hollow ball; 65, full bloom; and 67, majority of petals fallen), 4 ------ indicates the estimated period of infection by Taphrina deformans, $\longrightarrow$ indicates the period of symptom appearance on peach fruit. The percent value is the incidence of infected fruit. 
fruit were in the first stages of development, with all petals having fallen in the last days of March. Four wet periods occurred on 30 to 31 March and on 7 to 8,11 to 12 , and 16 to 17 April, with a WD of 25 to $42 \mathrm{~h}, 5$ to $49 \mathrm{~mm}$ of rainfall, and an average temperature between 10 and $12.3^{\circ} \mathrm{C}$. In late April and in May, other wet periods were registered, with shorter WD (14 to $17 \mathrm{~h}$ ) and higher Tw $\left(9\right.$ to $\left.19^{\circ} \mathrm{C}\right)$. The longest wet period occurred on 20 to 21 May, with $36 \mathrm{~h}$ of wetness at $14.6^{\circ} \mathrm{C}$. No periods with wetness longer than $12 \mathrm{~h}$ occurred during bloom.

In 2002 (Fig. 1B), fruit showed disease symptoms in the first 20 days of May. The final incidence of fruit infection was $54 \%$, while incidence of shoot infection $89 \%$. The period of infection was estimated to be between 9 April and 9 May, with complete petal fall occurring in the first days of April. No rainfall occurred during the entire blooming period, but there were long wet periods between 8 and 10 April and between 11 and 13 April, triggered by heavy rainfall ( 37 and $40 \mathrm{~mm}$ in total, respectively), with 44 to $54 \mathrm{~h}$ of wetness at 8 to $10^{\circ} \mathrm{C}$. Four additional wet periods occurred during the infection period, on 20 to 21 April (19 mm of rainfall, $25 \mathrm{~h}$ of wetness at $\left.12.3^{\circ} \mathrm{C}\right)$ and on $3(4 \mathrm{~mm}$, $\left.18.5 \mathrm{~h}, 16.9^{\circ} \mathrm{C}\right), 4\left(6 \mathrm{~mm}, 16.5 \mathrm{~h}, 16.5^{\circ} \mathrm{C}\right)$, and 8 to 10 May $\left(39 \mathrm{~mm}, 26 \mathrm{~h}, 16.1^{\circ} \mathrm{C}\right.$ ). The two events on 3 and 4 May were separated by only $6 \mathrm{~h}$ of dryness. Two shorter wet periods occurred later, on 11 and 24 May, triggered by 3 to $4 \mathrm{~mm}$ of rainfall, with 12 to $14 \mathrm{~h}$ of wetness at 15 to $18^{\circ} \mathrm{C}$.

In 2003 (Fig. 1C), no disease symptoms were observed on fruit, while $35 \%$ of the shoots showed leaf curl symptoms. During bloom there were two long wet periods, on 3 to 4 and 10 to 11 April, when 46 and $15 \mathrm{~mm}$ of rainfall triggered wet periods of 37 and $21 \mathrm{~h}$, respectively, at temperatures between 4.5 and $5.5^{\circ} \mathrm{C}$. Sporadic infections were observed on flowers, but they abscised soon after. After petal fall, four shorter wet periods occurred, 12 to $21 \mathrm{~h}$ long, with temperatures between 5.8 and $15.4^{\circ} \mathrm{C}$.

In 2004 (Fig. 1D), 63\% of the shoots were affected but only $3 \%$ of fruit showed disease symptoms by 1 May. The corresponding infection period was in the week around mid-April, soon after petal fall. The only wet period registered at that time was triggered by a rainfall of $25 \mathrm{~mm}$, with $30 \mathrm{~h}$ of wetness at $5.6^{\circ} \mathrm{C}$. No wet periods of at least $12 \mathrm{~h}$ occurred during bloom, while five periods of 12 to $18 \mathrm{~h}$ at 8.8 to $19.3^{\circ} \mathrm{C}$ occurred between the last 10 days of April and mid-May.

Relationships between weather and fruit infection. Based on the previously described observations, all of the 28 wet periods that occurred between the end of petal fall and the end of May (Fig. 1) were split into two groups, (i) 11 periods with infection and (ii) 17 periods without infection.

In the no-infection group, the average rainfall was $8.9 \mathrm{~mm}$ with a $99 \%$ confidence interval between 3.9 and $13.9 \mathrm{~mm}$. In the infection group, the average rainfall was $27.9 \mathrm{~mm}$, with $99 \%$ of data in the interval 12.1 to $43.7 \mathrm{~mm}$ (Table 1). Therefore, in $99 \%$ of the cases, no infection occurred with less than $12 \mathrm{~mm}$ of rainfall. The two distributions were significantly different at $P=$
0.035 , but there was a wide interval of rainfall values where the two groups overlapped (Fig. 2A).

Wet periods were always triggered by rainfall; no sufficient wetness (at least $12 \mathrm{~h}$ ) was supplied by dew or fog. When there was no infection, the average wet period was $16.8 \mathrm{~h}$ long, while it was $32.2 \mathrm{~h}$ long when infection occurred (Table 1). The two distributions were also significantly different $(P=0.0005)$, but the range of wetness durations where the two groups overlapped was narrow; this range included the fourth quartile of the group with no infection and the first quartile of the group with infection (Fig. 2B).

Tw was $13.9^{\circ} \mathrm{C}$ when infection did not occur, and $11.7^{\circ} \mathrm{C}$ in cases with infection (Table 1). Distributions of Tw for the two groups overlapped for all the temperatures lower than $17^{\circ} \mathrm{C}$ (Fig. 2C).

A logistic regression model accurately classified $89 \%$ of the wet periods: nine out of 11 periods with infection (82\%) and 16 of 17 periods without infection $(94 \%)$ were correctly estimated (Table 2). Only the duration of the wet period was included in the regression model after six iterations, while rainfall, temperature, and all interactions were not. The low values of the standard errors of parameters, the low deviance, and the high $R^{2}$ pointed out a good fit of the data (Table 3 ). This logistic regression model is written in the following form: Probability (infection) $=1 /\left(1+e^{-Z}\right)$, where $Z$ is the linear combination: $Z=-5.3215+0.2214 \mathrm{WD}$.

Based on this model, probability for infection to occur increased as WD increased, with probability $>0.5$ when $\mathrm{WD}>24$ h (Fig. 3). When WD increased by $1 \mathrm{~h}$, the odds increased by a factor of 1.25 , as shown in the $\exp (b)$ column of Table 3 . The odds are defined as the ratio of the probability that the event will occur to the probability that it will not.

Using a probability $>0.5$ to estimate an actual infection (i.e., WD $>24 \mathrm{~h}$ ), the regression failed to estimate an actual infection in only two cases (Table 2). This occurred on 3 and 4 May 2002, when wet periods of 18.5 and $16.5 \mathrm{~h}$ at 16 to $17^{\circ} \mathrm{C}$ were triggered by 4 and $6 \mathrm{~mm}$ of rainfall, respectively (Fig. 2A). Actually, these two wet periods were considered as separate events because the wetness sensor registered an interruption of $6 \mathrm{~h}$. It cannot be excluded that this dry period was shorter within the tree canopy and that there was only one prolonged wet period inciting infection.

The logistic regression model also incorrectly predicted an infection on 20 to 21 May 2001 (Table 2), when a wet period of $36 \mathrm{~h}$ at $14.6^{\circ} \mathrm{C}$ did not actually produce disease symptoms on fruit. Air temperature rapidly increased after this wet period: daily averages were consistently higher than $19^{\circ} \mathrm{C}$ after 22 May and probably stopped infection during incubation (27).

The logistic regression model did not include rainfall because there was a significant association between rainfall rates and the duration of wet periods $(r=0.66, P=0.00014)$. Nevertheless, rainfall had a key role.

To better investigate the role of rainfall, fruit were prevented from receiving rainfall by slipping some branches in plastic bags (in 2003) or by covering the tress (in 2004).

TABLE 1. Characterization of infection periods of Taphrina deformans on peach fruit in an orchard in Zattaglia (Northern Italy) from 2001 to 2004

\begin{tabular}{|c|c|c|c|c|c|c|}
\hline Weather variables & Infection $^{\mathrm{a}}$ & Mean & $P^{\mathrm{b}}$ & Standard deviation & Minimum & Maximum \\
\hline \multirow[t]{2}{*}{ Rainfall (mm) } & $\mathrm{No}^{\mathrm{c}}$ & 8.9 & 0.0009 & 7.97 & 0.2 & 27.0 \\
\hline & Yes & 27.9 & & 20.32 & 4.0 & 67.0 \\
\hline Wetness duration $(h)^{d}$ & No & 16.8 & 0.0026 & 5.52 & 12.0 & 36.0 \\
\hline \multirow[t]{2}{*}{ Temperature $\left({ }^{\circ} \mathrm{C}\right)^{\mathrm{e}}$} & No & 13.9 & 0.6496 & 3.94 & 5.8 & 19.3 \\
\hline & Yes & 11.7 & & 3.58 & 5.6 & 16.9 \\
\hline
\end{tabular}

${ }^{a}$ Infection occurrence was inferred as follows: first, it was considered that each wet period $>12 \mathrm{~h}$ had caused infection and the corresponding period of symptom onset was calculated using degree-days, based on the data of Table 5. When disease symptoms actually appeared, the corresponding wet period was considered a true infection period.

${ }^{\mathrm{b}}$ Probability level for the $t$ test for difference between means.

c "No" infection group had 17 cases; the "Yes" infection group 11 cases.

${ }^{\mathrm{d}}$ Hours of continuous wetness or interrupted for a maximum of $4 \mathrm{~h}$.

e Average air temperature during the wet period. 
In 2003, there was one wet period soon after petal fall (8 April), on 10 to 12 April, with $48 \mathrm{~mm}$ of rainfall, a WD of $26 \mathrm{~h}$ at $7.1^{\circ} \mathrm{C}$; thereafter, there were four rainfall events with WD less than $18 \mathrm{~h}$ (Fig. 1C). Fruit covered with the plastic bags did not receive the above-mentioned rainfall, but their surface was always wetted during the removal of the bags at the end of the rainfall, because of water condensation inside the bag. These fruit did not show infection by $T$. deformans, while $6 \%$ of those exposed were infected.

In 2004, the covered trees were wetted by misting for $48 \mathrm{~h}$ at a suitable temperature for infection (Table 4). Less than $1 \%$ of fruit were infected, with very few and small callus-like proliferations, in plants that had been wetted at petal fall ( 7 to 9 April), 2 and 3 weeks later, while no symptoms appeared in plants wetted during other periods. Covered plants that were not wetted for the entire experiment did not show any disease symptoms, while 5\% of the fruit were infected in the uncovered trees that were exposed to natural rainfall and wetness.

Weather conditions for infection. The minimum conditions for fruit infection were defined as at least $12 \mathrm{~mm}$ of rainfall with at least $24 \mathrm{~h}$ of wetness at a temperature $<17^{\circ} \mathrm{C}$, and with a temperature $<19^{\circ} \mathrm{C}$ during incubation. These conditions were validated with two independent data sets.

In potted peach plants exposed to natural $T$. deformans inoculum under trees severely affected by leaf curl, there were no infections when rainfall was $6.2 \mathrm{~mm}$ (group II) or $7.2 \mathrm{~mm}$ (group XII), irrespective of the corresponding wetness durations ( 9 and $35 \mathrm{~h}$, respectively) and temperatures (Tw and Tinc $<17^{\circ} \mathrm{C}$ ) (Table 5). Infection also did not occur in plants wetted for 9 to $19 \mathrm{~h}$, even if rainfall was 13 to $24 \mathrm{~mm}$ and temperatures were not at limiting values (groups III, V, VII, and X). In the remaining groups of plants, infection occurred on 14 to $32 \%$ of fruit which were exposed to more than $12 \mathrm{~mm}$ of rainfall with wetness durations between 28 and $50 \mathrm{~h}$ at 10 to $15^{\circ} \mathrm{C}$, and with incubation temperatures $<18^{\circ} \mathrm{C}$ (Table 5). In these fruit, the length of incubation ranged between 19 and 23 days. Incubation was 265 DD on average, with a 99\% confidence band between 240 and 290 DD.
In the orchards observed in 1996 and 1998, only one period with favorable conditions for infection occurred between petal fall and late May (Table 6) with 6\% of fruit infected in 1996, while in 1998 no infection occurred in 7 out of 8 cultivars, with $4 \%$ of 'Sweet Red' fruit infected. In 1997 and 1999, there were two favorable periods that resulted in $15 \%$ of fruit becoming infected at the end of May (Table 6). In 2005, there was only one favorable period with long wetting and suitable temperature, between 9 and 12 April. In the orchard in Reda, plants were again at bloom and less than $1 \%$ infection occurred on fruit; in the orchards in Cesena and Zattaglia, full petal fall occurred before this favorable period, resulting in 7 to $10 \%$ infected fruit (Table 6). Disease pressure was very high in all the above-mentioned orchards, with 60 to $100 \%$ of shoots infected.

Considering the entire set of data collected in the orchards (Fig. 1 and Table 6), there was a close relationship between the incidence of infected fruit and the number of favorable periods that occurred between petal fall and late May $(r=0.95, P=0.000005)$ or the total wetness duration (as a summation of wet hours during each favorable period) $(r=0.81, P=0.003)$. Fruit infection increased from traces to about $60 \%$ as the number of periods favorable to infection increased from none to 4 . Furthermore, with one favorable period, infected fruit increased from 1 to $3 \%$ to 7 to $10 \%$ when total wetness increased from about 30 to 75 h (Fig. 4).

TABLE 2. Classification of infection periods of Taphrina deformans on peach fruit in an orchard in Zattaglia (Northern Italy) from 2001 to 2004, based on predictions of the logistic regression shown in Table 3

\begin{tabular}{lccc}
\hline & \multicolumn{2}{c}{ Estimated $^{\mathrm{a}}$ infection } & \\
\cline { 2 - 3 } Observed infection & No & Yes & $\%$ \\
\hline No & 16 & 1 & 94.1 \\
Yes & 2 & 9 & 81.8 \\
$\%$ & 88.9 & 90.0 & 89.3 \\
\hline
\end{tabular}

a Estimated infections are infections with a probability $>0.5$, that correspond to wetness duration (WD) $>24 \mathrm{~h}$ (Fig. 3).
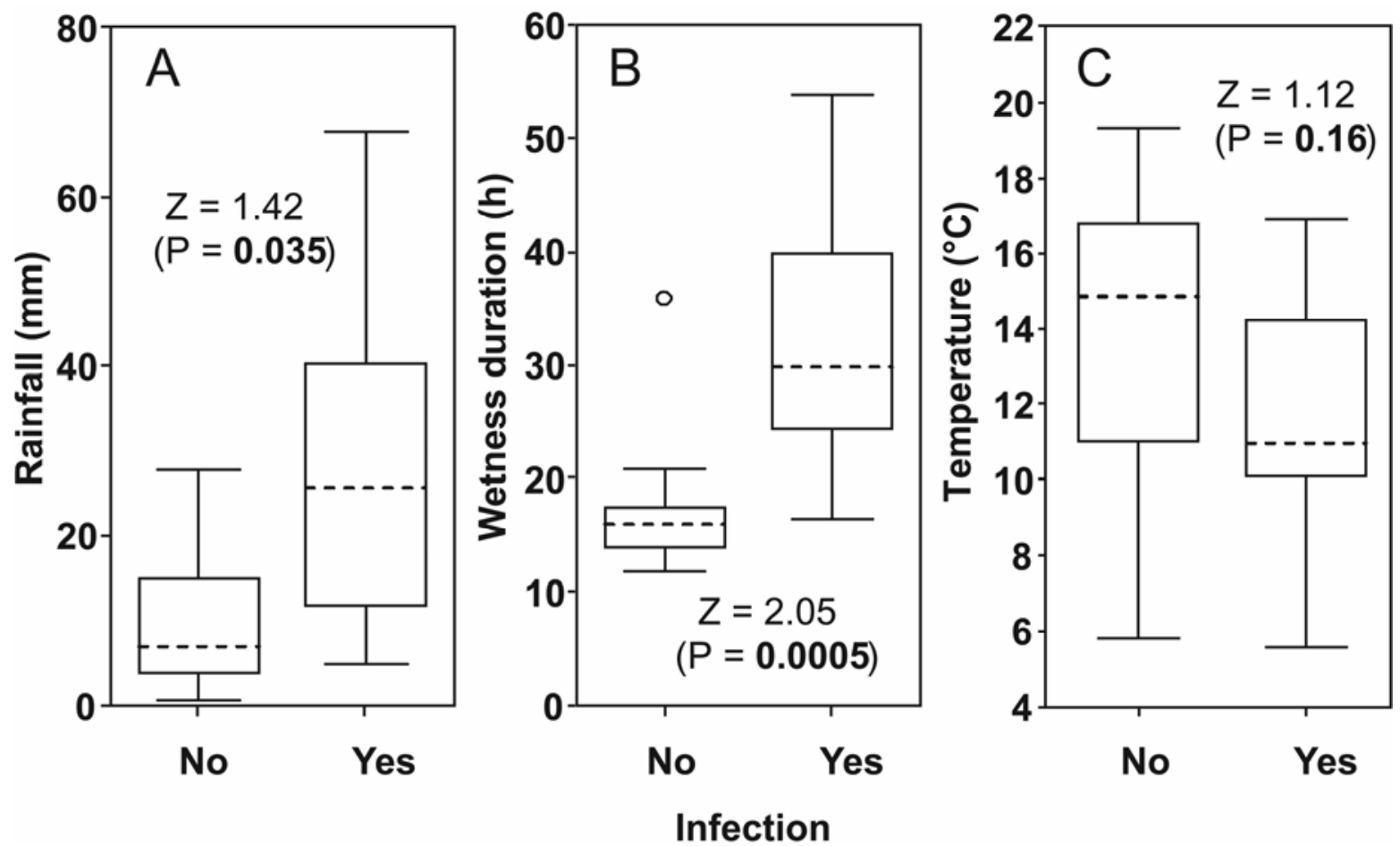

Fig. 2. Box and whisker plots showing A, the distribution of rainfall, $\mathbf{B}$, duration of wetness, and $\mathbf{C}$, temperature during wetness for the wet periods shown in Figure 1, separated into two groups: with or without fruit infection by Taphrina deformans. The $Z$ values were calculated using the Kolmogorov-Smirnov test under the null hypothesis that the two groups belong to the same distribution. Boxes include $50 \%$ of data, dotted lines indicate the median, and whiskers extend to minimum and maximum values, while circles are outliers. 


\section{DISCUSSION}

This work presents the first published findings on conditions favoring infection of peach fruit by $T$. deformans. Minimum weather conditions for fruit infection were determined from orchard observations under natural conditions or in trees managed to exclude rainfall. These conditions were validated using potgrown peach plants exposed to single infection events and independent orchard observations.

The method used to determine weather conditions for fruit infection from orchard observations has been used previously to determine conditions for shoot infection (27). It assumes that the amount of $T$. deformans inoculum was not a limiting factor for infection. Although the amounts of inoculum were not measured, this assumption appears true because, (i) the work was performed in orchards that were severely affected by leaf curl in previous years, (ii) spores of $T$. deformans in these orchards are usually abundant (29), and (iii) disease incidence on shoots ranged between $35 \%$ in 2003 , when weather conditions were unfavorable for shoot infection (27), to $89 \%$ in 2002 . Furthermore, since a discrete trait of the disease (infection or not) was considered and not a quantitative one (incidence or severity), the possible effect of the inoculum dose must be considered negligible.

In the orchard evaluated, fruit infection ranged between traces to $50 \%$ of the fruit infected. Therefore, infection of peach fruit may be considered a cause of direct losses in peach yield in addition to indirect losses in both fruit yield and quality due to a reduction in photosynthetic rate in the severely affected shoots (23). These direct losses are probably underestimated because it is commonly believed that infected fruit drop early in the season $(24,34)$, and plants can attenuate losses by regulating fruit abscission during summer. Abscission usually occurs in June in a single wave of different intensity and duration, and results in the stunting and drop of the less competitive fruit $(18,35)$. In contrast with the common opinion, the majority of infected fruit included in these studies remained in the tree until harvest, with appreciable direct yield losses.

Fruit became susceptible after petal fall, so weather conditions occurring before this growth stage did not influence the incidence of infected fruit. This finding explains the fact that shoot infection, which depends on environmental conditions and occurs between bud break and petal fall when shoots are highly susceptible (27), is not closely associated with fruit infection (25). This finding is somewhat obvious, but it had never been demonstrated before. During bloom, the ovary, which will develop to form the drupe, is completely covered by sepals and petals that likely prevent infection. In fact, sporadic infections observed on flowers during the rainy periods in 2003 caused swelling and distortion in sepals and petals, and flowers dropped rapidly.

Wetness duration was a key factor for peach fruit infection. At least $24 \mathrm{~h}$ of continuous wetness, interrupted by no more than $4 \mathrm{~h}$, were necessary for infection to occur, but the rainfall exclusion experiments demonstrated that rainfall is also necessary for infection. Fruit protected from rainfall did not develop symptoms though wetted for a long time, while those exposed were infected. The sporadic symptoms observed on the covered fruit in 2004 were likely caused by the runoff of water from other parts of the tree to fruit during the $48 \mathrm{~h}$ of misting that splashed the epiphytic blastospores present on the surfaces of the covered trees (29). The absence of leaf curl in covered peach trees has been previously demonstrated for shoot infection only $(6,13,20,21)$. Brunelli and Ponti (6) observed that, in Northern Italy, disease incidence on fruit between 1988 and 1992 increased with increasing amounts of rainfall and numbers of rainfall events occurred during early fruit development.

Under the conditions observed in this work, no infection occurred with less than $12 \mathrm{~mm}$ of rainfall, both in orchard observations and in potted peach trees exposed to single rainfall events. Wetness and rainfall have also been found to be essential factors for infection of peach shoots $(10,27)$, but the minimum values

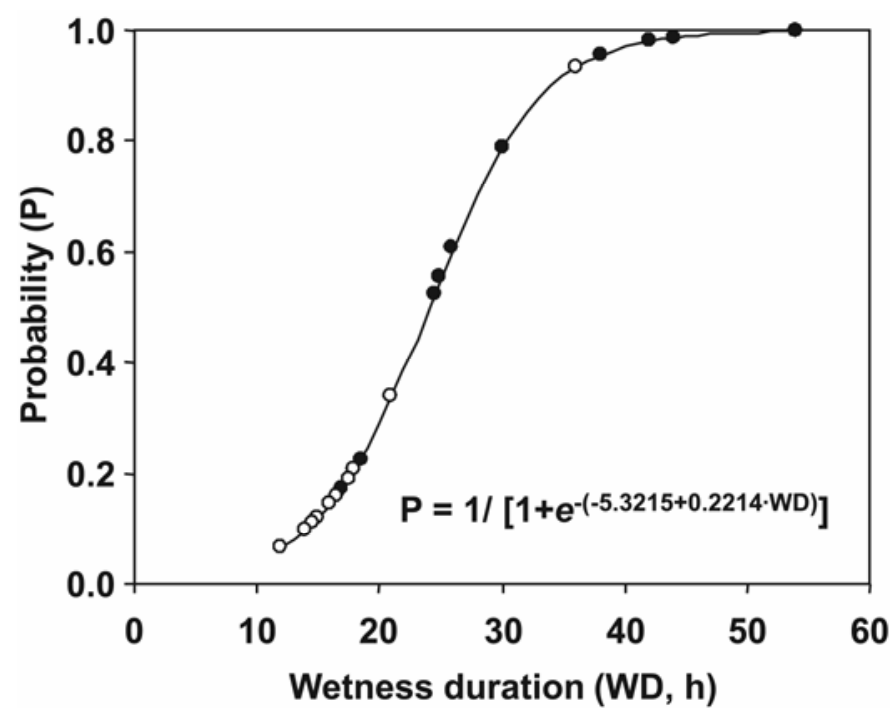

Fig. 3. Predicted probability of infection of peach fruit by Taphrina deformans as a function of wetness duration, estimated by a logistic regression. Points show the estimated probability for the observed wetness durations, while the solid line is the estimated probability for the remaining cases: $\$$ and $\%$ show wet periods leading or not to an observed infection. Statistics for the regression are shown in Table 3.

TABLE 4. Frequency of peach fruit infected by Taphrina deformans in plants that were covered to exclude rainfall and wetted by misting for $48 \mathrm{~h}$ during different periods after bloom, in covered plants with no wetting, and in noncovered plants that were exposed to rainfall and wetness

\begin{tabular}{|c|c|c|c|c|}
\hline Wet periods (48 h) & $\mathrm{Tw}^{\mathrm{a}}\left({ }^{\circ} \mathrm{C}\right)$ & $\operatorname{Tinc}^{\mathrm{b}}\left({ }^{\circ} \mathrm{C}\right)$ & Total fruit $(n)$ & $\begin{array}{l}\text { Infected } \\
\text { fruit }(\%)\end{array}$ \\
\hline 24-26 $\mathrm{March}^{\mathrm{c}}$ & 7.3 & 12.1 & 300 & 0.0 \\
\hline 7-9 April $^{\mathrm{d}}$ & 7 & 16.5 & 280 & 0.7 \\
\hline 14-16 April & 9.2 & 14.3 & 342 & 0.0 \\
\hline 21-23 April & 14.1 & 17.4 & 295 & 0.3 \\
\hline 28-30 April & 13.8 & 16.5 & 360 & 0.3 \\
\hline 4-6 May & 12.2 & 17.2 & 330 & 0.0 \\
\hline 13-15 May & 12.2 & 16.0 & 340 & 0.0 \\
\hline No wetting & & & 318 & 0.0 \\
\hline Not covered & & & 321 & 5.4 \\
\hline
\end{tabular}

a Average air temperature under the cover during the wet period.

b Average temperature during incubation; when the disease did not appear average was calculated over the 21 days following the beginning of the wet period.

c Full bloom.

d Petal fall.

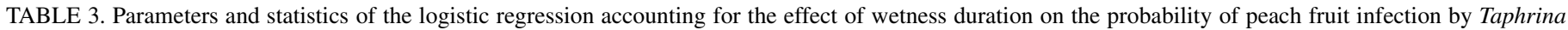
deformans

\begin{tabular}{|c|c|c|c|c|c|c|c|c|}
\hline Variables ${ }^{\mathrm{a}}$ included & $b$ & S.E. & Wald's statistic & df & $P$ & $\operatorname{Exp}(b)$ & Deviance & $R^{2 \mathrm{~b}}$ \\
\hline Constant & -5.3215 & 1.845 & 8.32 & 1 & 0.004 & 0.005 & 21.5 & 0.59 \\
\hline Wetness duration (WD) & 0.2214 & 0.086 & 6.59 & 1 & 0.010 & 1.248 & & \\
\hline
\end{tabular}

a The logistic regression is probability (infection) $=1 /\left(1+e^{-(-5.3215+0.2214 \mathrm{WD})}\right)$.

b Coefficient of determination adjusted following Nagelkerke (22). 
were different from those found for fruit: $3 \mathrm{~mm}$ of rainfall instead of $12 \mathrm{~mm}$, and $12 \mathrm{~h}$ of wetness instead of $24 \mathrm{~h}$. The reasons for the differences between conditions making infection possible on shoots and on fruit were not investigated. Most likely, shoot tips may retain water more efficiently than fruit surfaces because of the morphology of young leaves. The longer wetness duration required for fruit infection may imply that spore germination and germ tube growth on fruit surfaces is slower than on shoot tips. It is known that the abundant hydrophilic sugars present on the surfaces of young leaves stimulate germination of $T$. deformans blastospores (8) and probably make this process faster than on young and immature fruit, where the concentration of the secreted sugars is low (12).

Air temperatures during both the wet period and the subsequent incubation period were also crucial for successful infection on shoots, with infection occurring only when air temperature was $<16^{\circ} \mathrm{C}$ and $<19^{\circ} \mathrm{C}$, respectively (27). Results obtained with fruit were in full agreement with those mentioned above for shoots. In all experiments, no infection was observed with temperatures $\geq 17^{\circ} \mathrm{C}$ during the wet period. Moreover, in the only case when an estimated infection failed to develop (20 to 21 May 2001), the air temperature during incubation was $>19^{\circ} \mathrm{C}$. Very little information is available in the literature on the effect of temperature on fruit infection. Kornilov (17) observed that fruit were infected less frequently than leaves, usually after a cold spring.
On the peach plants exposed to isolated rainfall events, the length of incubation was about 3 weeks, which corresponded to 240 to $290 \mathrm{DD}$ (base $0^{\circ} \mathrm{C}$ ) after the beginning of rainfall. In the orchard, the time interval between the occurrence of suitable environmental conditions and disease onset was consistent with the above-mentioned data. Literature data on the effect of incubation length on peach shoots were in total agreement with that observed on fruit. Rossi et al. (27) found a linear relationship between air temperature and incubation length in infected shoots; based on this relationship, the average incubation period at 8 to $19^{\circ} \mathrm{C}$ is 20 days and 254 DD. In another study, Rossi et al. (29) observed that the incubation period under orchard conditions was 21 days on average between 1999 and 2002, which corresponded to 262 DD.

Based on the results of this work, we conclude that the period for peach fruit infection by $T$. deformans is relatively short, occurring between petal fall and the time when air temperature consistently exceeds $16^{\circ} \mathrm{C}$. Before petal fall, fruit are not susceptible and rarely infected flowers drop before fruit development. At temperatures higher than $16^{\circ} \mathrm{C}$, infection is prevented, and with temperature $>19^{\circ} \mathrm{C}$ during incubation, infection may abort. During the above mentioned period, rainfall and the duration of the wet period triggered by rainfall have key roles in infection occurrence. At least $12 \mathrm{~mm}$ of rainfall are necessary to splash an effective inoculum dose from the peach tree surface to fruit. After-

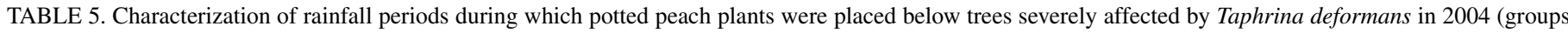
I to VI) and 2005 (groups VII to XII) to investigate the effect of weather conditions on fruit infection

\begin{tabular}{|c|c|c|c|c|c|c|c|c|}
\hline \multirow[b]{2}{*}{ Plant group ${ }^{a}$} & \multirow[b]{2}{*}{ Rain (mm) } & \multirow[b]{2}{*}{$\mathrm{WD}^{\mathrm{b}}(\mathrm{h})$} & \multirow[b]{2}{*}{$\mathrm{Tw}^{\mathrm{c}}\left({ }^{\circ} \mathrm{C}\right)$} & \multicolumn{3}{|c|}{ Incubation } & \multirow[b]{2}{*}{ Total fruit $(n)$} & \multirow{2}{*}{$\begin{array}{c}\text { Infected fruit } \\
(\%)\end{array}$} \\
\hline & & & & Days & Tinc $^{d}$ & Degree-days & & \\
\hline \multicolumn{9}{|l|}{2004} \\
\hline I & 21.0 & 37 & 10.2 & 19 & 11.6 & 220 & 21 & 14.3 \\
\hline II & 6.2 & 9 & 11.5 & - & 13.2 & - & 15 & 0.0 \\
\hline III & 13.2 & 17 & 8.3 & - & 14.6 & - & 27 & 0.0 \\
\hline IV & 12.8 & 29 & 12.8 & 20 & 11.1 & 226 & 18 & 22.2 \\
\hline V & 22.6 & 17 & 16.8 & - & 15.2 & - & 29 & 0.0 \\
\hline VI & 12.2 & 39 & 14.9 & 19 & 17.3 & 334 & 17 & 17.6 \\
\hline \multicolumn{9}{|l|}{2005} \\
\hline VII & 23.6 & 19 & 7.9 & - & 16.3 & - & 25 & 0.0 \\
\hline VIII & 14.2 & 50 & 14.5 & 22 & 10.7 & 236 & 31 & 32.3 \\
\hline IX & 15.0 & 28 & 13.8 & 23 & 12.4 & 286 & 16 & 18.8 \\
\hline$X$ & 24.2 & 9 & 13.3 & - & 12.8 & - & 18 & 0.0 \\
\hline XI & 18.0 & 30 & 14.6 & 19 & 14.9 & 289 & 22 & 22.7 \\
\hline XII & 7.2 & 35 & 11.8 & - & 16.1 & - & 31 & 0.0 \\
\hline
\end{tabular}

a A group consists of three plants.

$\mathrm{b}$ Wetness duration: hours of continuous wetness, interrupted for a maximum of $4 \mathrm{~h}$.

c Average air temperature during the wet period.

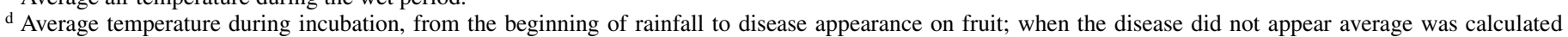
over the 21 days following the beginning of rainfall.

${ }^{\mathrm{e}}$ Degree-days were calculated by accumulating the daily air temperature (base $0^{\circ} \mathrm{C}$ ) between the beginning of rainfall and disease appearance on fruit.

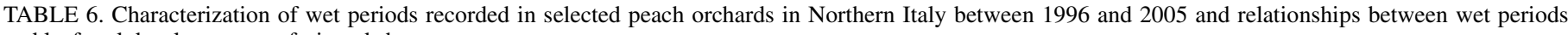
and leaf curl development on fruit and shoots

\begin{tabular}{|c|c|c|c|c|c|c|c|c|c|}
\hline \multirow[b]{2}{*}{ Year } & \multirow[b]{2}{*}{ Location } & \multirow[b]{2}{*}{ Cultivar } & \multirow[b]{2}{*}{ Petal fall } & \multirow[b]{2}{*}{ Wet period } & \multirow[b]{2}{*}{ Rain mm } & \multirow[b]{2}{*}{$\mathrm{WD}^{\mathrm{a}}(\mathrm{h})$} & \multirow[b]{2}{*}{$\mathrm{Tw}^{\mathrm{b}}\left({ }^{\circ} \mathrm{C}\right)$} & \multicolumn{2}{|c|}{ Disease incidence $(\%)$} \\
\hline & & & & & & & & Fruit & Shoots \\
\hline 1996 & Conselice & 'Caldesi' & 22 April & 28 April-1 May & 24 & 55 & 14.4 & 6 & 83 \\
\hline \multirow[t]{2}{*}{1997} & Cesena & 'O'Henry' & 30 March & 20-22 April & 95 & 57 & 10.7 & 15 & 96 \\
\hline & & & & 5-8 May & 18 & 83 & 15.2 & & \\
\hline 1998 & Cesena & Various $^{\mathrm{c}}$ & 13-25 March & 3-5 May & 63 & 34 & 13.4 & $0-4$ & $62-82$ \\
\hline \multirow[t]{2}{*}{1999} & Zattaglia & 'Julia’' & 4 April & 8-9 April & 27 & 31 & 10.5 & 15 & 90 \\
\hline & & & & 27-29 April & 24 & 44 & 13.5 & & \\
\hline \multirow[t]{3}{*}{2005} & Reda & 'Big Top' & 14 April & 9-12 April & 77 & 73 & 9.5 & $<1$ & 69 \\
\hline & Cesena & 'Red Gold' & 10 April & 9-12 April & 92 & 74 & 9.8 & 7 & 93 \\
\hline & Zattaglia & 'Caldesi' & 9 April & 10-12 April & 71 & 61 & 8.3 & 10 & 100 \\
\hline
\end{tabular}

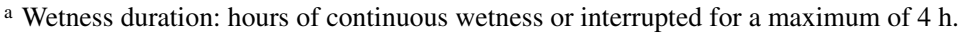

b Average air temperature during the wet period.

c 'Early Star', 'Alessandra', 'Sweet Red', 'Guglielmina', 'Star Crest', 'Bienvenue', 'Zaiger', and 'Zincal'. 
wards, at least $24 \mathrm{~h}$ of continuous wetness, interrupted for no more than $4 \mathrm{~h}$, are necessary for infection to occur. Disease symptoms appear after an incubation of about 3 weeks, which is equivalent to 240 to 290 DD. A close relationship exists between the incidence of fruit affected by $T$. deformans and both the number of favorable events and the total duration of wetness during such events.

Damp and cool weather conditions likely influence infection in different manners. Rainfall may be responsible for splashing of blastospores from the foliage to fruit (29), while the film of water may provide humidity for spore germination and penetration (31). Since the pathogen penetrates the cuticle mainly by physical means $(4,31)$ in the presence of a film of water $(27)$, the thickness of the cuticle may also influence infection, as well as its wettability, which depends on epicuticular wax deposition and composition (7). Both cuticle development and epicuticular wax deposition on plant surfaces occur in response to heat and water stress (19). During cloudy, cool and damp weather, there is little danger from heat or water loss, and trees therefore may produce only a thin cuticle and deposit fewer amounts of epicuticular waxes to protect the newly formed and enlarging fruitlets (16); as a consequence, the probability for successful fruit infection may increase.

Results from the present work increase information about relationships between weather conditions and leaf curl infection on peach. Safran and Levy (30) have incorporated their information about the role of rainfall and temperature into a model estimating the probability of leaf curl infection occurring under Israeli conditions over a period of 6 weeks after bud break. Giosuè et al. (15) validated the Israeli model in the Po Valley (Northern Italy) and modified the minimum conditions of both temperature and rainfall for infection to occur. The modified model was accurate in determining the time of leaf curl infection on shoots, but not in estimating its severity. Further studies dealt with weather effects on inoculum dynamics $(28,29)$ and determined quantitative relationships between shoot infection, rainfall, wetness duration, and temperature, and better defined the period of shoot susceptibility $(26,27)$. The same analysis was performed in this work for peach fruit.

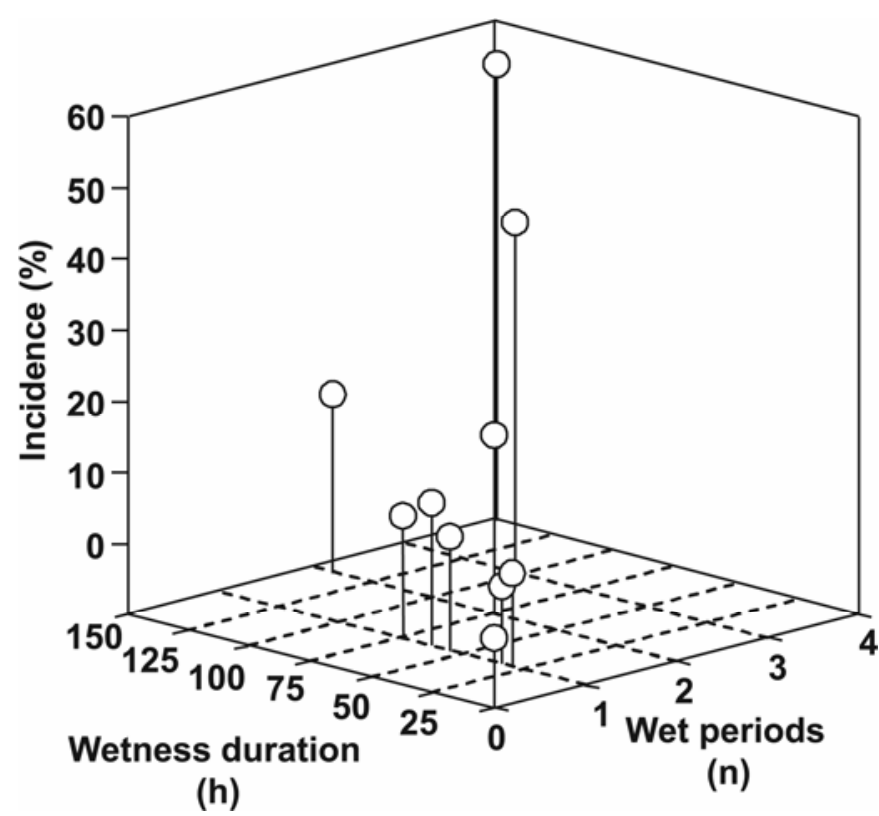

Fig. 4. Relationship between incidence of peach fruit infected by Taphrina deformans, the number of favorable wet periods, and the total duration of wetness over such periods, occurring between petal fall (late March to midApril) and late May in the orchards of Figure 1 and Table 6. Favorable wet periods are defined as periods with at least $24 \mathrm{~h}$ of continuous wetness, interrupted by a maximum of $4 \mathrm{~h}$, triggered by at least $12 \mathrm{~mm}$ of rainfall, with temperatures $<17^{\circ} \mathrm{C}$ during the wet period and $<19^{\circ} \mathrm{C}$ during incubation.

\section{LITERATURE CITED}

1. Agresti, A. 2002. Categorical Data Analysis. Wiley \& Sons Inc., 2nd ed. Hoboken, NJ.

2. Agrios, G. N. 1988. Plant Pathology. Academic Press Inc., New York.

3. Anonymous, 1997. Compendium of Growth Stage Identification Keys for Mono- and Dicotyledonous Plants. Extended BBCH scale. 2nd ed. BBA, BSA, IGZ, IVA, AgrEVO, BASF, Bayer, and Novartis, Basel.

4. Bassi, M., Conti, G. G., and Barbieri, N. 1984. Cell wall degradation by Taphrina deformans in host leaf cells. Ultrastructural and cytochemical observations. Mycopathologia 88:115-125.

5. Brunelli, A., Ponti, I., Spada, L., Emiliani, G., Cont, C., Tosi, C., Guardifni, P., and Garaffoni, M. 1992. Acquisizione sperimentali sulla difesa del pesco dalla bolla. Inf. Fitopatol. 42:51-61.

6. Brunelli, A., and Ponti, I. 1993. Observations sur l'épidémiologie et essais de lutte contre la cloque du pêcher. IOBC WPRS Bull. 16:64-67.

7. Bukovac, M. J., Flore, J. A., and Baker, E. A. 1979. Peach leaf surfaces: Changes in wettability, retention, cuticular permeability, and epicuticular wax chemistry during expansion with special reference to spray application. J. Am. Soc. Hortic. Sci. 104:611-617.

8. Caporali, L. 1966. Nouvelles observations sur la biologie et sur le parasitisme du Taphrina deformans (Berk.) Tul. Pages 36-42 in: Proc. 1st Congress of the Mediterranean Phytopathological Union. Firenze University Press, Firenze, Italy.

9. Commonwealth Mycological Institute. 1981. Taphrina deformans. Distribution Maps of Plant Diseases. Edition 4. Map 192. Commonwealth Mycological Institute, Kew, England.

10. Cook, R. T. A., and Baker, H. 1982. Peach leaf curl. Garden 107:449-453.

11. Flint, M. L. 2000. Leaf curl. Pest notes. Published online by the University of California, publication 7426 (http://www.ipm.ucdavis.edu).

12. Fourie, J. F., and Holz, G. 1998. Effects of fruit and pollen exudates on growth of Botrytis cinerea and infection of plum and nectarine fruit. Plant Dis. 82:165-170.

13. Gandolfi, C. 1915. Alcune osservazioni sull'Exoascus del pesco. Coltivatore 14:435-437.

14. Geoffrion, R. 1981. La cloque du pêcher. Phytoma 325:7-8.

15. Giosuè, S., Spada, G., Rossi, V., Carli, G., and Ponti, I. 2000. Forecasting infections of the leaf curl disease on peaches caused by Taphrina deformans. Eur. J. Plant Pathol. 106:563-571.

16. Gradziel, T. M., Bostock, R. M., and Adaskaveg, J. E. 2003. Resistance to brown rot disease in peach is determined by multiple structural and biochemical components. Acta Hortic. 622:347-352.

17. Kornilov, A. V. 1977. Peach leaf curl. Zash. Rast. 12:57.

18. Martin, G. C. 1973. Peach fruit-set and abscission. Acta Hortic. 34:345352.

19. Martin J. T., and Juniper, C. E. 1970. The Cuticles of Plants. Edward Arnold, London.

20. Morgas, H., and Mika, A. 2005. Pages 81-84 in: Fruit trees cultivation under polyethylene tent as alternative method of stone fruit production to conventional (standard) production. Proc. International Conference on Environmentally Friendly Fruit Growing, Polli, Estonia.

21. Mundy, C. W. A. 1974. Peach leaf curl. Garden 99:460-461

22. Nagelkerke, N. J. D. 1991. A note on a general definition of the coefficient of determination. Biometrika 78:691-692.

23. Prakash, S, and Nautiyal, M. C. 1988. Assessment of fruit yield and quality losses due to leaf curl (Taphrina deformans) in peach cv. Flordasun. Prog. Hortic. 20:161-166.

24. Pscheidt, J. W. 1995. Leaf curl. Page 22 in: Compendium of Stone Fruit Diseases. J. M. Ogawa, E. I. Zehr, G. W. Bird, D. F. Ritchie, K. Uriu, and J. K. Uyemoto, eds. American Phytopathological Society, St. Paul, MN.

25. Rossi, V., Bolognesi, M., Giosuè, S., Mazzini, F., Ponti, I., and Spada, G. 2005. Biologia ed epidemiologia dell'agente della bolla del pesco. Inf. Agric. 10:59-67.

26. Rossi, V., and Giosuè, S. 2006. Pages 326-329 in: A new model for Taphrina deformans infection on peaches. Proc. 12th Congress of Mediterranean Phytopathological Union, Rhodes Island, Greece.

27. Rossi, V., Bolognesi, M., Languasco, L., and Giosuè, S. 2006. Influence of environmental conditions on infection of peach shoots by Taphrina deformans. Phytopathology 96:155-163.

28. Rossi, V., and Languasco, L. 2007. Influence of environmental conditions on spore production and budding in Taphrina deformans, the causal agent of peach leaf curl. Phytopathology 97:352-358.

29. Rossi, V., Bolognesi, M., and Giosuè, S. 2007. Seasonal dynamics of Taphrina deformans inoculum in peach orchards. Phytopathology 97:359365 .

30. Safran, E., and Levy, Y. 1995. Essai de conception d'un modèle de prévision contre la cloque du pêcher. Agronomie 15:49-57.

31. Schneider, A., and Dargent, R. 1977. Localisation et comportement du mycelium de Taphrina deformans dan le mesophylle et sous la cuticule des feuilles de pêcher (Prunus persica). Can. J. Bot. 55:2485-2495. 
32. Simeone, A. M. 1984. Sensibilità varietale del pesco delle nettarine ai principali parassiti vegetali. Ann. Ist. Sper. Fruttic. 15:17-28.

33. Spada, G., Carli, G., Ponti, I., Giosuè, S., and Rossi, V. 2001. Use of a model simulating Taphrina deformans infection on peaches for optimal disease control. IOBC WPRS Bull. 24:319-324.
34. vonBroembsen, S., Olson, B., and Pratt, P. W. 2004. Leaf Curl of Peaches and Nectarines. Oklahoma Cooperative Extension Fact Sheets F-7639 (http://pods.dasnr.okstate.edu/ docushare/dsweb/View/Collection-217).

35. Zucconi, F. 1978. Peach fruit abscission: The mode of action of thinning agents. Acta Hortic. 80:245-256. 